\title{
Heavy-metal pollution of the river Rhine and Meuse floodplains in the Netherlands
}

\author{
H. Middelkoop ${ }^{1}$ \\ ${ }^{1}$ Centre for Geo-ecological Research - ICG, Utrecht University, Department of Physical \\ Geography, P.O. Box 80.115, 3508 TC UTRECHT, the Netherlands; \\ e-mail: h.middelkoop@geog.uu.nl
}

Manuscript received: 11 November 1998; accepted in revised form: 9 June 2000

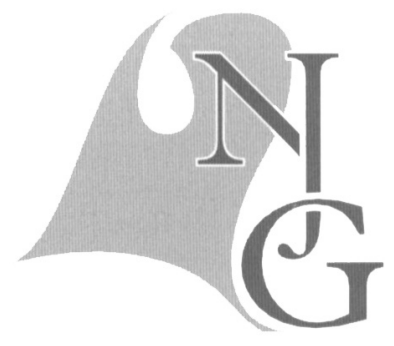

\begin{abstract}
The embanked floodplains of the lower Rhine river in the Netherlands contain large amounts of heavy metals, which is a result of many years of deposition of contaminated overbank sediments. The metal pollution varies greatly between the various floodplain sections as well as in vertical direction within the floodplain soil profiles. The present contribution describes the key processes producing the spatial variability of the metal pollution in floodplain soils: (1) spatial patterns of the concentrations and deposition of $\mathrm{Cd}, \mathrm{Cu}, \mathrm{Pb}$ and $\mathrm{Zn}$ during a single flood, which have been determined from samples collected after a high-magnitude flood event; (2) the pollution trends of the lower Rhine over the past 150 years, which were reconstructed on the basis of metal concentrations in sediments from small ponds within the floodplain area. During the flood the largest metal depositions $\left(0.03 \mathrm{~g} / \mathrm{m}^{2} \mathrm{Cd}, 0.7 \mathrm{~g} / \mathrm{m}^{2} \mathrm{Cu}, 1.1 \mathrm{~g} / \mathrm{m}^{2} \mathrm{~Pb}\right.$ and $5.0 \mathrm{~g} / \mathrm{m}^{2} \mathrm{Zn}$ for the Rhine) occurred along the natural levees, decreasing to about one third of these values at larger distance from the river. Deposition of heavy metals occurred since the end of the nineteenth century. Periods of maximum pollution occurred in the 1930s and 1960s, when $\mathrm{Cu}, \mathrm{Pb}$ and $\mathrm{Zn}$ concentrations were about 6-10 times as high as background values.

The resulting metal distribution in the floodplain soil profiles is illustrated by means of typical examples. Maximum metal concentrations in floodplain soils vary from 30 to $130 \mathrm{mg} / \mathrm{kg}$ for $\mathrm{Cu}$, from 70 to $490 \mathrm{mg} / \mathrm{kg}$ for $\mathrm{Pb}$, and from 170 to 1450 $\mathrm{mg} / \mathrm{kg}$ for $\mathrm{Zn}$. The lowest metal pollution is found in the distal parts of floodplain sections with low flooding frequencies, where average sedimentation rates have been less than about $5 \mathrm{~mm} / \mathrm{a}$. The largest metal accumulations occur in low-lying floodplain sections where average sedimentation rates have been more than $10 \mathrm{~mm} / \mathrm{a}$.
\end{abstract}

Keywords: floodplain sedimentation, heavy-metal contamination

\section{Introduction}

Due to pollution of the Rhine and Meuse rivers over many years, considerable amounts of heavy metals have accumulated in the overbank sediments of the embanked floodplains of their lower river reaches. Several studies have been carried out in order to map the metal pollution of these floodplains (a.o., Hoogerwerf, 1992). It is often attempted in such inventory studies to predict metal concentrations in the floodplain soils by establishing empirical relationships with factors that are assumed to determine differences in sedimentation rate. In spite of some successful results obtained at small floodplain sections (Rang et al., 1987; Leenaers, 1989; Burrough et al., 1993; Rikken \& Van Rijn, 1993), Hoogerwerf (1992) found - in a large-scale inventory for the entire Rhine and Meuse floodplain - only weak correlations for metal concentrations in surface samples versus flooding frequency and local elevation. In addition, the amounts of pollutants appeared at some places to be much higher at several decimetres depth than at the surface. Because of the apparent low predictive value of such statistical relationships for surface samples, a better knowledge was needed of the proces- 
ses that have caused the present-day distribution of the metals in the floodplain soils.

The present contribution deals with the spatial variability of metal pollution of floodplain soils, which is controlled primarily by deposition of contaminated overbank sediments during flood events. Spatial variations in floodplain sedimentation rates and metal deposition during flood events were determined using measurements of the deposition of contaminated overbank sediments along the lower Rhine and Meuse reaches during a high-magnitude flood. This process alone is, however, insufficient to explain the variability in pollution depth. The metal concentrations in the river sediment have greatly varied during the twentieth century, resulting in corresponding variations in the metal concentrations in vertical direction within the floodplain soils. These temporal changes in metal contamination of the Rhine were reconstructed

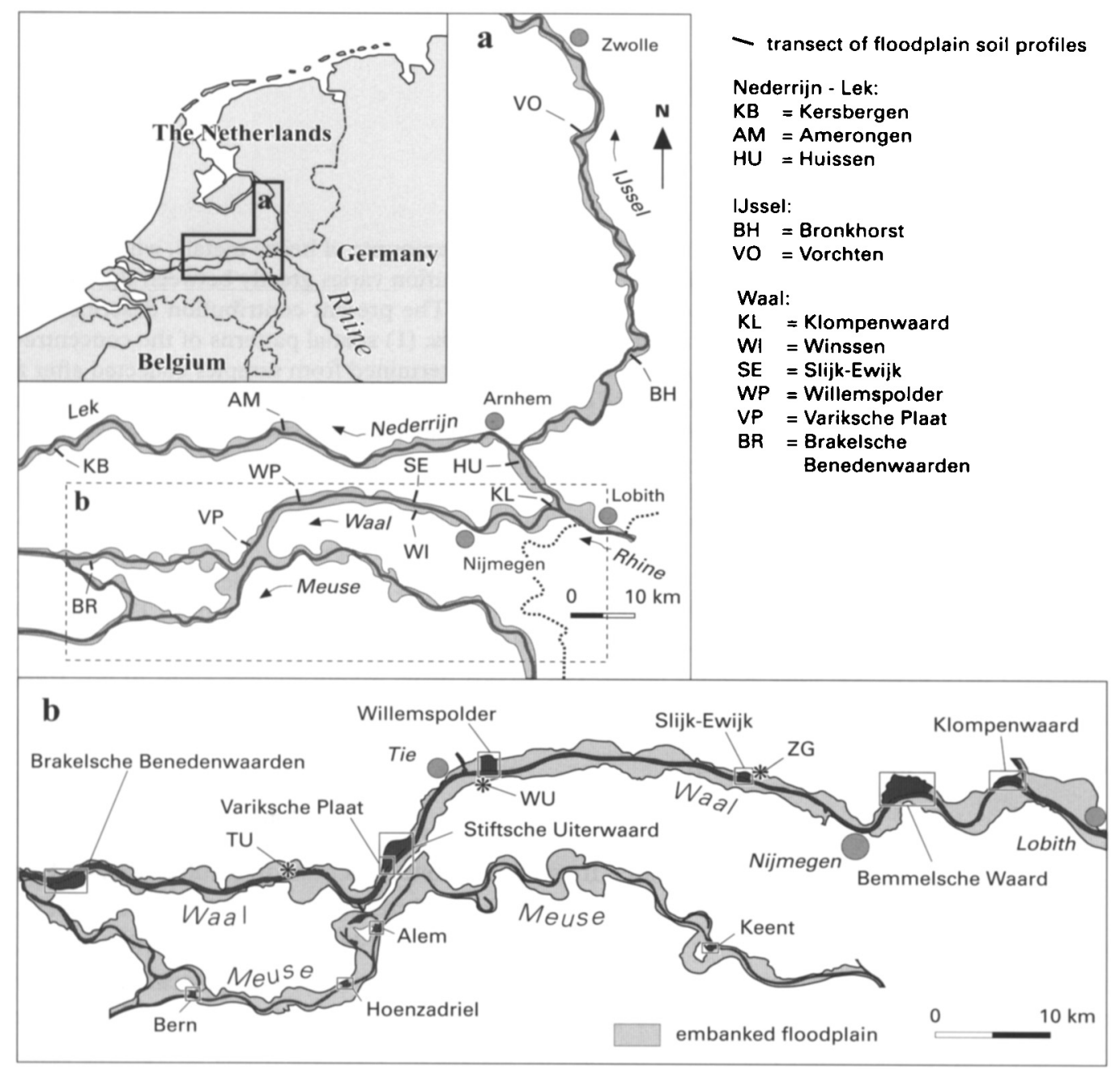

floodplain section where sediment-trap measurements were carried out during the December 1993 flood

* dike-breach pond; $Z G$ = Zwarte Gat; $W U$ = Wamel; $T U$ = Tuil

Fig. 1. Location of the sample areas.

a: floodplain soil profiles.

b: sediment traps during the December 1993 flood, and dike-breach ponds. from dated sediment cores from small ponds within the floodplain. The resulting spatial variability of the metal pollution of the floodplains is discussed by means of a series of metal profiles in floodplain soils from various sites along the distributaries of the lower Rhine reaches.

\section{Sample collection}

\section{Deposition of sediment and heavy metals}

Deposition of $\mathrm{Cd}, \mathrm{Cu}, \mathrm{Pb}$ and $\mathrm{Zn}$ on the floodplains was measured during the high-magnitude flood of December 1993. Sediments deposited during the flood were collected using about 800 sediment traps, consisting of pliable mats of artificial grass of $50 \mathrm{~cm} \times 50 \mathrm{~cm}$ size, placed on seven floodplain sections along the Waal river and four sections along the Meuse river (Fig. 1).

$$
\begin{aligned}
& \text { Nederrijn - Lek: } \\
& \mathrm{KB}=\text { Kersbergen } \\
& \mathrm{AM}=\text { Amerongen } \\
& \mathrm{HU}=\text { Huissen } \\
& \mid \mathrm{Jssel}: \\
& \mathrm{BH}=\text { Bronkhorst } \\
& \mathrm{VO}=\text { Vorchten } \\
& W \mathrm{Wal}: \\
& \mathrm{KL}=\text { Klompenwaard } \\
& W 1=\text { Winssen } \\
& \mathrm{SE}=\text { Slijk-Ewijk } \\
& W P=\text { Willemspolder } \\
& \mathrm{VP}=\text { Variksche Plaat } \\
& \mathrm{BR}=\text { Brakelsche } \\
& \text { Benedenwaarden }
\end{aligned}
$$

- transect of floodplain soil profiles

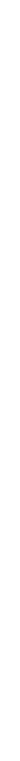


The sample areas comprised floodplain sections with natural topography (Klompenwaard, Varikse Plaat, Brakel, Hoenzadriel, parts of Slijk-Ewijk and Stiftsche Uiterwaard), levelled sections (Bemmelsche Waard, Willemspolder, Keent, Alem, Bern), floodplain sections bordered by a natural levee (Klompenwaard, Slijk-Ewijk, Keent, Bern) and sections bordered by a minor dike that protects the floodplain from inundation during low-magnitude floods (Bemmelsche Waard, Willemspolder, Stiftsche Uiterwaard). The sampling was performed along transects perpendicular to the main channel.

\section{Lake sediment from ponds}

Sediment cores were obtained from three small ponds located within the embanked floodplain area: Zwarte Gat (ZG), Wamel (WU) and Tuil (TU) (Fig. 1). These ponds are the scars of historic dike breaches and for more than two centuries they have been functioning as natural sediment traps in which 3 to $6 \mathrm{~m}$ thick bodies of dark-grey overbank sediments have accumulated (Middelkoop, 1997).

The cores were taken from a raft using a modified Livingstone piston corer. In the laboratory, the sediment cores were cut along the longer axis into two halves. At about $10-\mathrm{cm}$ intervals, samples of a constant volume were taken to determine the compaction of the sediment. At intervals of about $10-20 \mathrm{~cm}$, samples were taken for the analysis of the clay and organic-matter contents and metal concentrations. To achieve an age/depth framework, 5-11 samples were taken from each core for ${ }^{210} \mathrm{~Pb}$-dating.

\section{Floodplain soils}

Samples of floodplain soils were collected from 29 vertical profiles from 11 floodplain sections along the lower Rhine distributaries (Nederrijn/Lek, IJssel and Waal) (Fig. 1a). These sites comprise different flooding frequencies, local elevations and distance to the main river channel (Table 1). The samples from the upper $50 \mathrm{~cm}$ were taken using a gouge; samples at greater depth were collected using a hand auger. The

Table 1. Site characteristics of the locations of the investigated soil profiles.

\begin{tabular}{|c|c|c|c|c|}
\hline & $\begin{array}{l}\text { average flood } \\
\text { freqency }(n / 100 a)\end{array}$ & $\begin{array}{l}\text { average flood } \\
\text { time (days/a) }\end{array}$ & $\begin{array}{l}\text { distance from } \\
\text { levee }(\mathrm{m})\end{array}$ & site description \\
\hline \multicolumn{5}{|c|}{ Nederrijn-Lek } \\
\hline 1 AM1 & 35 & 1.5 & 150 & natural levee \\
\hline 2 AM2 & 35 & 1.5 & 550 & central part of floodplain \\
\hline 3 AM3 & 35 & 1.5 & 790 & central part of floodplain \\
\hline $4 \mathrm{~KB} 2$ & 25 & 1.0 & 60 & central part of floodplain, behind minor dike \\
\hline $5 \mathrm{~KB} 3$ & 25 & 1.0 & 170 & central part of floodplain \\
\hline $6 \mathrm{HU1}$ & 55 & 3.8 & 170 & natural levee \\
\hline 7 HU2 & 45 & 2.5 & 400 & behind minor dike \\
\hline $8 \mathrm{HU} 3$ & 45 & 2.5 & 430 & behind minor dike, depression \\
\hline \multicolumn{5}{|l|}{ Iffsel } \\
\hline $9 \mathrm{BH} 1$ & 90 & 6 & 330 & central part of floodplain \\
\hline $10 \mathrm{BH} 2$ & 90 & 6 & 20 & natural levee \\
\hline $11 \mathrm{VO} 1$ & 110 & 8 & 50 & natural levee \\
\hline $12 \mathrm{VO} 2$ & 110 & 8 & 190 & central part of floodplain \\
\hline \multicolumn{5}{|l|}{ Waal } \\
\hline $13 \mathrm{KL} 1$ & 120 & 8 & 260 & central part of low floodplain \\
\hline $14 \mathrm{KL} 2$ & 120 & 8 & 50 & part of low floodplain \\
\hline$-\mathrm{KL3}$ & 120 & 8 & 120 & central part of floodplain, depression \\
\hline 15 WI4 & 40 & 1.8 & 220 & behind minor dike, elevated area \\
\hline 16 WI5 & 45 & 2.5 & 20 & natural levee \\
\hline 17 SE1 & 100 & 7 & 50 & behind natural levee, elevated area \\
\hline $18 \mathrm{SE} 2$ & 100 & 7 & 180 & behind natural levee, depression \\
\hline $19 \mathrm{WPl}$ & 44 & 2.2 & 670 & central part of floodplain, behind minor dike \\
\hline $20 \mathrm{WP} 2$ & 44 & 2.2 & 250 & central part of floodplain, behind minor dike \\
\hline 21 WP3 & 44 & 2.2 & 360 & depression, behind minor dike \\
\hline 22 WP4 & 44 & 2.2 & 610 & depression, behind minor dike \\
\hline $23 \mathrm{VP1}$ & 80 & 5.4 & 380 & central part of low floodplain \\
\hline 24 BR1 & 62 & 4.4 & 10 & depression behind natural levee \\
\hline $25 \mathrm{BR} 2$ & 11 & $<1$ & 480 & central part of floodplain, behind minor dike \\
\hline $26 \mathrm{BR} 3$ & 40 & 1.8 & 210 & central part of floodplain, behind minor dike \\
\hline 27 BR4 & 11 & $<1$ & 360 & central part of floodplain, behind minor dike \\
\hline 28 BR5 & 11 & $<1$ & 480 & central part of floodplain, behind minor dike \\
\hline
\end{tabular}


sampling intervals were $2.5-5 \mathrm{~cm}$ in the upper $20 \mathrm{~cm}$ of the profiles and $5-10 \mathrm{~cm}$ at greater depths.

\section{Analytical methods}

The contents of clay (particles $<2 \mu \mathrm{m}$ ), organic matter, and heavy metals were determined for each sample from the sediment traps, the dike-breach cores, and the floodplain soil profiles. The percentage of clay in the samples was determined using the standard pipette method after NEN 5753 (NNI, 1992a). The organic matter contents were determined by loss on ignition after NEN 5754 (NNI, 1992b). The concentrations of $\mathrm{Cd}, \mathrm{Cu}, \mathrm{Pb}$ and $\mathrm{Zn}$ in the samples were measured by ICP-AES after extraction using $2 \mathrm{M}$ $\mathrm{HNO}_{3}$ in a microwave. Extensive testing has demonstrated that the metal concentrations obtained using this extraction method differed only by $3 \%$ (except Cd: $13 \%$ ) from extraction results obtained using aqua regia (NEN 6465: NNI, 1981; Middelkoop, 1997). The sediment collected by the traps was oven dried at $70^{\circ} \mathrm{C}$ and subsequently weighed. The metal deposition was calculated by taking the product of the amount of deposited sediment measured using the traps and the metal concentrations in the sediment. The metal concentrations in the samples from the dike-breach cores and the soil profiles were converted to standard concentrations in a reference sediment type containing $40 \%$ of clay and $8 \%$ of organic matter. This was done using linear relationships between metal concentrations and the contents of clay and organic matter of the floodplain sediments deposited in 1993. The dry bulk densities of the sediment cores from the ponds were determined by measuring the weights of the samples with constant volume after oven drying at $70^{\circ} \mathrm{C}$. These densities were used to correct the depth scales of the profiles for compaction. The ${ }^{210} \mathrm{~Pb}$ analyses were carried out at the Netherlands Institute for Sea Research (NIOZ), Texel, the Netherlands. The ${ }^{210} \mathrm{~Pb}$ activity in the samples was measured by alpha-spectrometry emitted by its granddaughter ${ }^{210} \mathrm{Po}$ (Heijnis et al., 1987).

Sedimentation rates were obtained according to the so-called constant sedimentation (CR) model (Dominik et al., 1981) after plotting the sample excess ${ }^{218} \mathrm{~Pb}$ activities (in $\mathrm{Bq} / \mathrm{kg}$ ) originating from deposition on a logarithmic scale against the compaction-corrected depth. Errors in the measurements of ${ }^{219} \mathrm{~Pb}$ activities were about $5 \mathrm{~Bq} / \mathrm{kg}$ and the precision of the estimated sedimentation rates was about $0.2 \mathrm{~cm} / \mathrm{a}$. Middelkoop (1997) and Middelkoop \& Asselman (1998) give a more complete description of the methods.

\section{Deposition of heavy metals during the flood of December 1993}

\section{Particulate-bound metal concentrations in the river}

Figure 2 shows the suspended-sediment concentrations and the concentrations of particulate-bound $\mathrm{Cu}, \mathrm{Pb}$ and $\mathrm{Zn}$ in the Rhine and Meuse sediment during the flood of December 1993. Average metal concentrations in Rhine sediment measured during the flood at Lobith (German/Dutch border) were about $1.6 \mathrm{mg} / \mathrm{kg}$ for $\mathrm{Cd}, 64 \mathrm{mg} / \mathrm{kg}$ for $\mathrm{Cu}, 90 \mathrm{mg} / \mathrm{kg}$ for $\mathrm{Pb}$ and $400 \mathrm{mg} / \mathrm{kg}$ for $\mathrm{Zn}$. These concentrations were lower than during the preceding period of low discharge. During the flood, the Meuse sediment at the Belgian/Dutch border contained $5-7 \mathrm{mg} / \mathrm{kg} \mathrm{Cd}$, $50-60 \mathrm{mg} / \mathrm{kg} \mathrm{Cu}, 220 \mathrm{mg} / \mathrm{kg} \mathrm{Pb}$ and $670 \mathrm{mg} / \mathrm{kg} \mathrm{Zn}$.

Table 2. Contents of clay, organic matter and heavy metals in sediments deposited on the Waal and Meuse floodplains during the flood of December 1993.

\begin{tabular}{|c|c|c|c|c|c|c|}
\hline & & minimum & maximum & average & median & standard deviation \\
\hline \multicolumn{7}{|c|}{ Waal $(n=41)$} \\
\hline$<2 \mu \mathrm{m}$ & (mass \%) & 5.7 & 47.9 & 27.3 & 30.3 & 10.5 \\
\hline org. matter & (mass \%) & 1.5 & 12.2 & 6.5 & 6.8 & 2.2 \\
\hline & $(\mathrm{mg} / \mathrm{kg})$ & 0.3 & 3.0 & 1.9 & 2.1 & 0.5 \\
\hline $\mathrm{Cu}$ & $(\mathrm{mg} / \mathrm{kg})$ & 10.4 & 81.5 & 57.1 & 63.8 & 17.0 \\
\hline $\mathrm{Pb}$ & $(\mathrm{mg} / \mathrm{kg})$ & 26.4 & 126 & 89.1 & 94.6 & 22.2 \\
\hline $\mathrm{Zn}$ & $(\mathrm{mg} / \mathrm{kg})$ & 152 & 462 & 344 & 379 & 76.6 \\
\hline \multicolumn{7}{|c|}{ Meuse $(n=17)$} \\
\hline$<2 \mu \mathrm{m}$ & (mass \%) & 4.6 & 40.0 & 24.8 & 28.5 & 12.7 \\
\hline org. matter & (mass \%) & 0.7 & 11.2 & 6.4 & 6.9 & 3.3 \\
\hline $\mathrm{Cd}$ & $(\mathrm{mg} / \mathrm{kg})$ & 0.5 & 12.1 & 7.1 & 7.5 & 3.9 \\
\hline $\mathrm{Cu}$ & $(\mathrm{mg} / \mathrm{kg})$ & 3.0 & 110 & 62.5 & 71.0 & 33.7 \\
\hline $\mathrm{Pb}$ & $(\mathrm{mg} / \mathrm{kg})$ & 17.2 & 344 & 188 & 202 & 99.5 \\
\hline $\mathrm{Zn}$ & $(\mathrm{mg} / \mathrm{kg})$ & 93.7 & 1177 & 684 & 707 & 339 \\
\hline
\end{tabular}




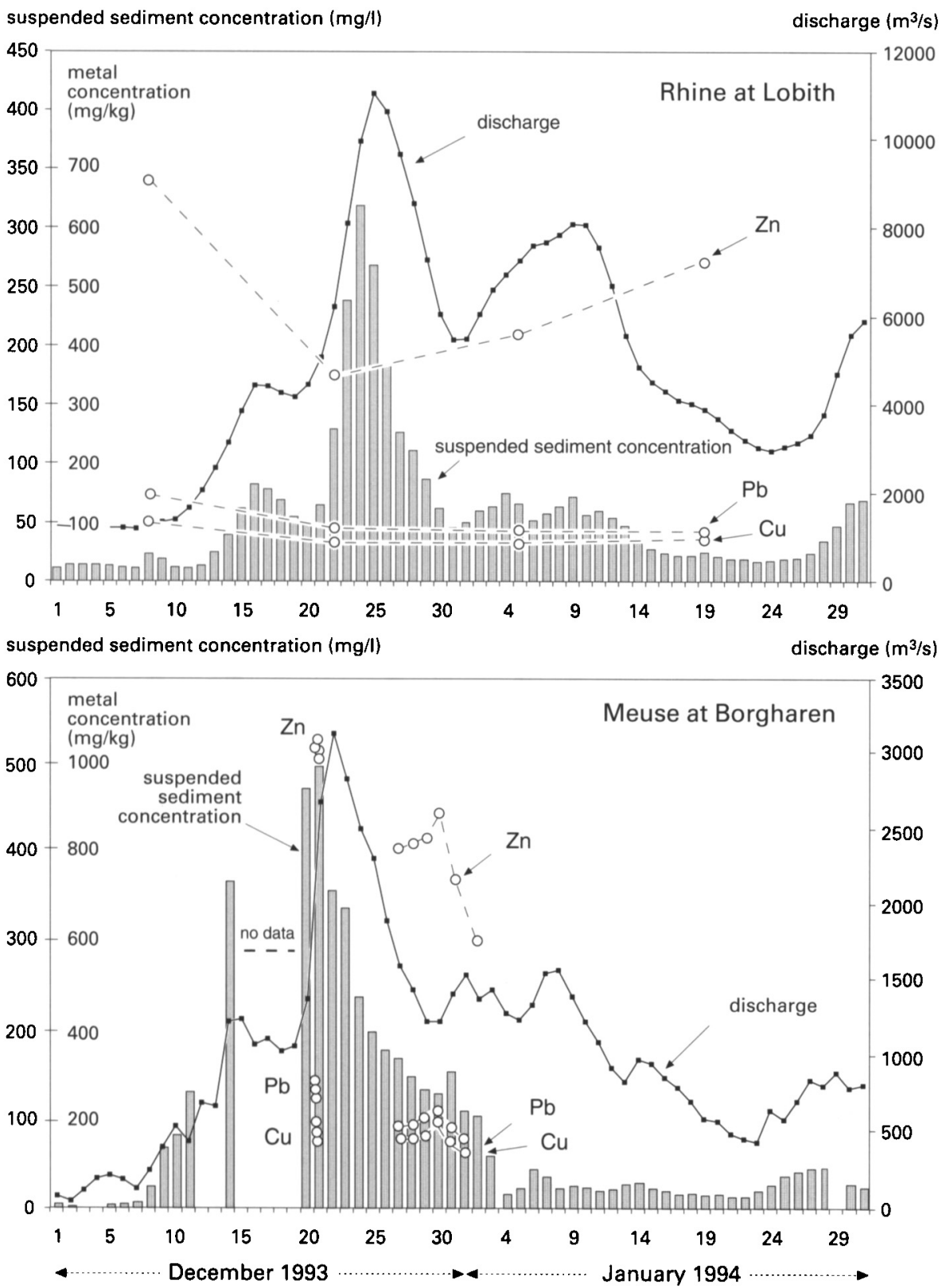

Fig. 2. Discharge, suspended-sediment concentration and metal concentrations in the sediment of the Rhine at Lobith (top) and the Meuse at Borgharen (bottom) during the flood of December 1993. Sedimentation on the embanked floodplains of both rivers occurred between December 21, 1993 and January 13, 1994. Source: Institute for Inland Water Management and Waste Water Treatment (RIZA) (unpublished data) and $\operatorname{Kos}(1994)$.

Concentrations of $\mathrm{Cd}, \mathrm{Cu}, \mathrm{Pb}$ and $\mathrm{Zn}$ in overbank deposits

Table 2 summarises the heavy-metal concentrations in the samples from the sediment deposited during the flood of December 1993 on the floodplains along the Waal and Meuse. A wide range of concentrations was found for all metals. The average and standard deviations of metal concentrations in the Waal samples are lower than those found in the samples from the Meuse.

Figures 3-5 show typical examples of the composition and amounts of overbank sediments deposited during the flood of December 1993. Large differences in metal concentrations were found along the transects of the Klompenwaard (Fig. 3b), Brakel, Keent and Bern (Fig. 5b) sections, whereas the concentrations in the Willemspolder and within the cen- tral parts of the Bemmelsche Waard (Fig. 4b), the Slijk-Ewijk section and Varikse Plaat varied less. The strongest gradients in metal concentrations occurred in floodplain sections with a pronounced natural levee (e.g., Klompenwaard and Bern; Figs. 3b and $5 b)$. The changes in metal concentrations coincide with those of the clay and organic matter contents. Metal concentrations in the sandy material deposited directly behind the natural levee are relatively low, but the contents of clay, organic matter and heavy metals increase with distance from the natural levee. In floodplain sections bordered by a minor dike, only the finer sediment fraction with high metal concentrations was deposited.

Variations in metal concentrations within a floodplain section are mainly determined by the clay and organic matter contents of the sediment. Figure 6 

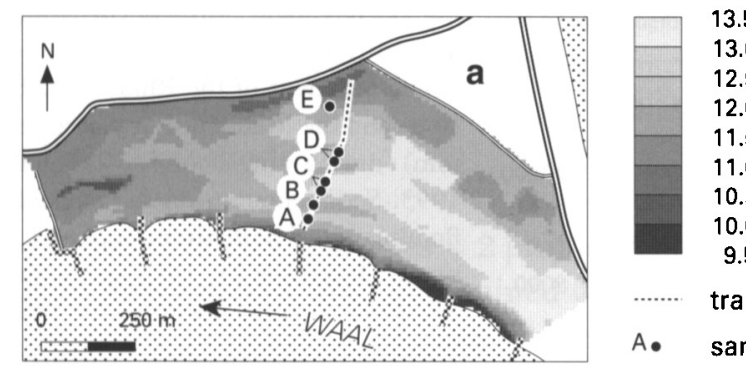

…... transect of sediment traps

A. sample location
Fig. 3. Klompenwaard: sediment composition and heavy-metal deposition.

a: floodplain elevation and sampling cross-section.

b: cross-section: contents of clay, organic matter and heavy metals in overbank sediments.

c: cross-section: deposition of sediment and heavy metals.
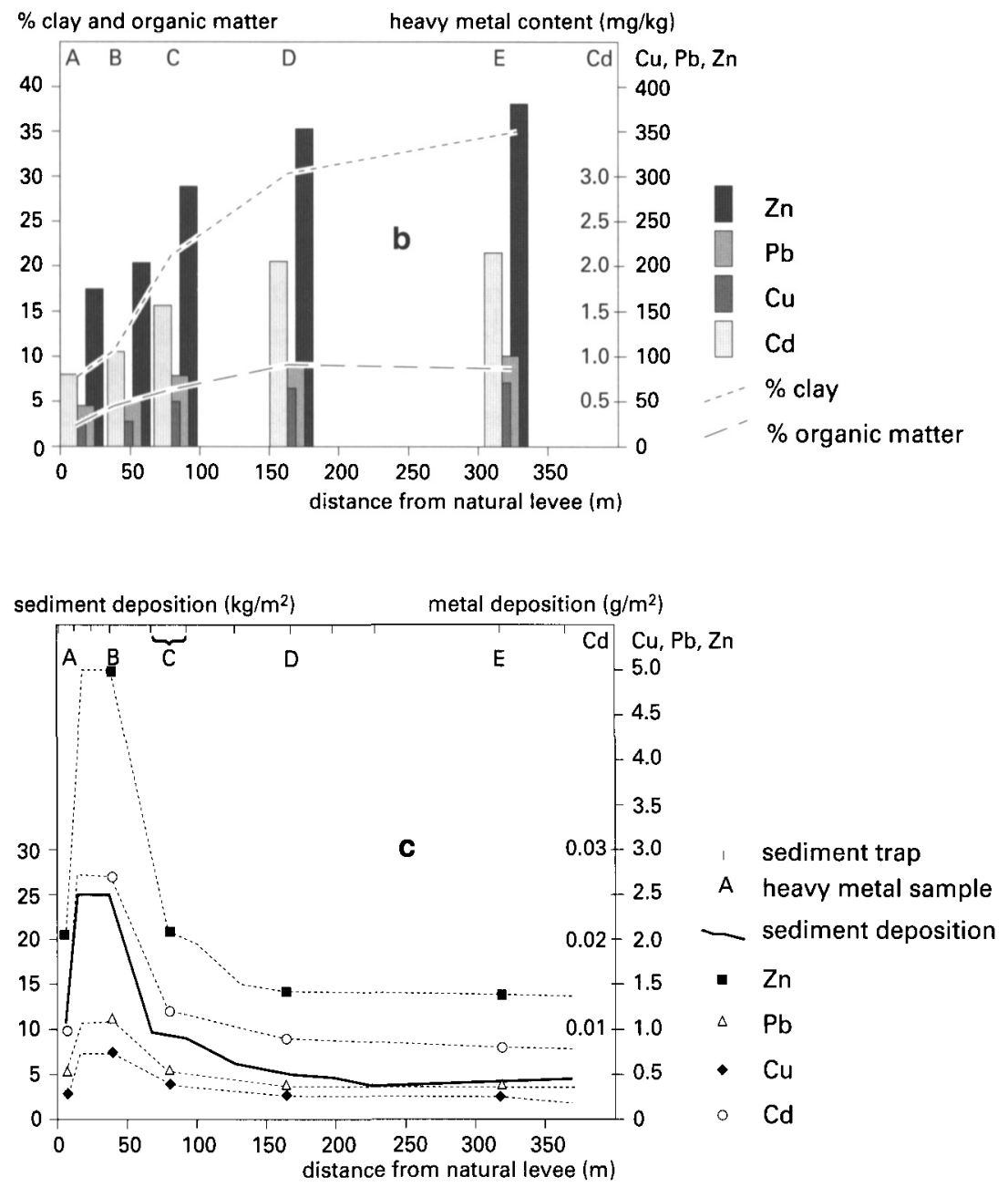

shows by the example of $\mathrm{Zn}$ the correspondence between metal concentrations and the percentages of clay and organic matter in the sediment. $\mathrm{Zn}$ was chosen for illustration because its concentrations are highest. The increments of linear regressions of the metal concentrations on the clay and organic matter contents (Table 3) can be considered as a measure of the degree of pollution of the river in the upstream basin (Middelkoop, 1997). The larger increments of metal concentrations for the Meuse sediments show that these are more contaminated than the Rhine sediments.

\section{Metal deposition}

Figures $3 c, 4 c$ and $5 c$ demonstrate that the spatial variation of metal deposition is dominated by the amount of sediment deposition. The decrease in total sediment deposition with increasing distance from the main channel is much larger than the increase in metal concentrations associated with changes in clay and organic-matter contents.

High-maximum metal depositions occurred within $50 \mathrm{~m}$ distance from the top of the natural levee of the Klompenwaard $\left(0.03 \mathrm{~g} / \mathrm{m}^{2} \mathrm{Cd}, 0.7 \mathrm{~g} / \mathrm{m}^{2} \mathrm{Cu}, 1.1 \mathrm{~g} / \mathrm{m}^{2}\right.$ $\mathrm{Pb}$ and $\left.5.0 \mathrm{~g} / \mathrm{m}^{2} \mathrm{Zn}\right)$ and Bern $\left(0.06 \mathrm{~g} / \mathrm{m}^{2} \mathrm{Cd}, 0.75\right.$ 

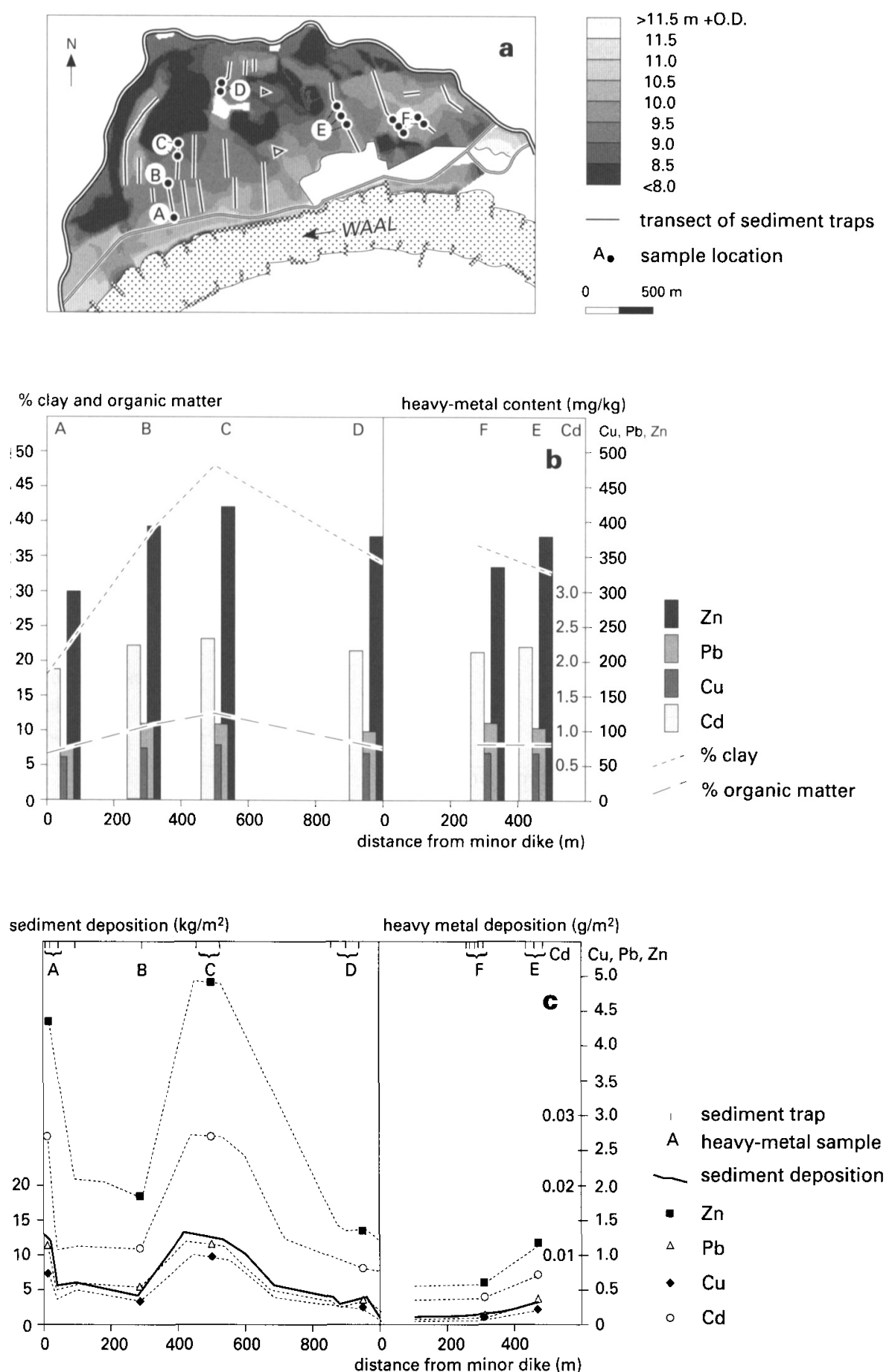

$\mathrm{g} / \mathrm{m}^{2} \mathrm{Cu}, 1.4 \mathrm{~g} / \mathrm{m}^{2} \mathrm{~Pb}$ and $6.0 \mathrm{~g} / \mathrm{m}^{2} \mathrm{Zn}$ ) sections (Figs. $3 \mathrm{c}$ and $5 \mathrm{c}$ ). At larger distances from the river, the metal deposition decreased to about one third (along the Waal) or one fifth (along the Meuse) of these maximum values. Large metal deposition due to high sediment accumulation behind the natural levee or minor dike was also found in the sections of Slijk-Ewijk, Willemspolder, Stiftsche Uiterwaard and Varikse Plaat. Within the Bemmelsche Waard (Fig. $4 c)$, the highest metal deposition occurred in the low-lying area around sample point $\mathrm{C}$, where large
Fig. 4. Bemmelsche Waard: sediment composition and heavy-metal deposition.

a: floodplain elevation and sampling cross-section.

b: cross-section: contents of clay, organic matter and heavy metals in overbank sediments.

c: cross-section: deposition of sediment and heavy metals. amounts of sediment with high contents of clay and organic material were deposited.

Total metal deposition on the Waal floodplain during the flood of December 1993

The total amount of silt and clay deposited on the Waal floodplains during the flood was estimated from the sediment-trap measurements to be $240 \cdot 10^{6} \mathrm{~kg}$. The total sand deposition, determined in a separate study (Van Manen et al., 1994), was about $350 \cdot 10^{6}$ 

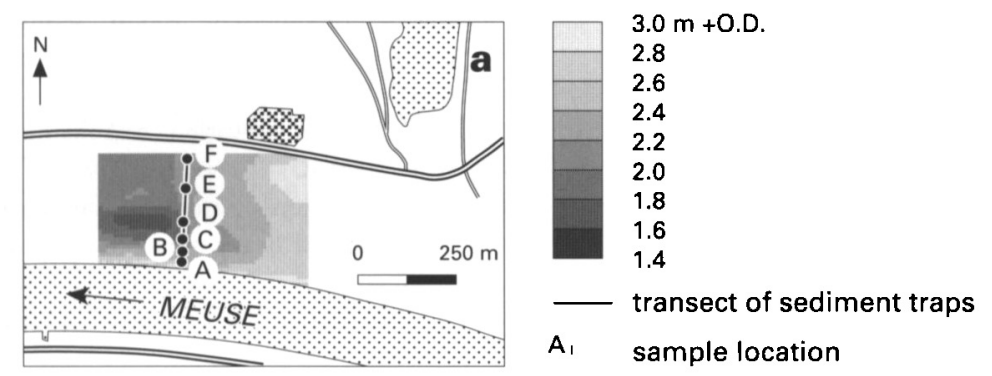

$A_{1}$ sample location
Fig. 5. Bern: sediment composition and heavy-metal deposition.

a: floodplain elevation and sampling cross-section.

b: cross-section: contents of clay, organic matter and heavy metals in overbank sediments.

c: cross-section: deposition of sediment and heavy metals.
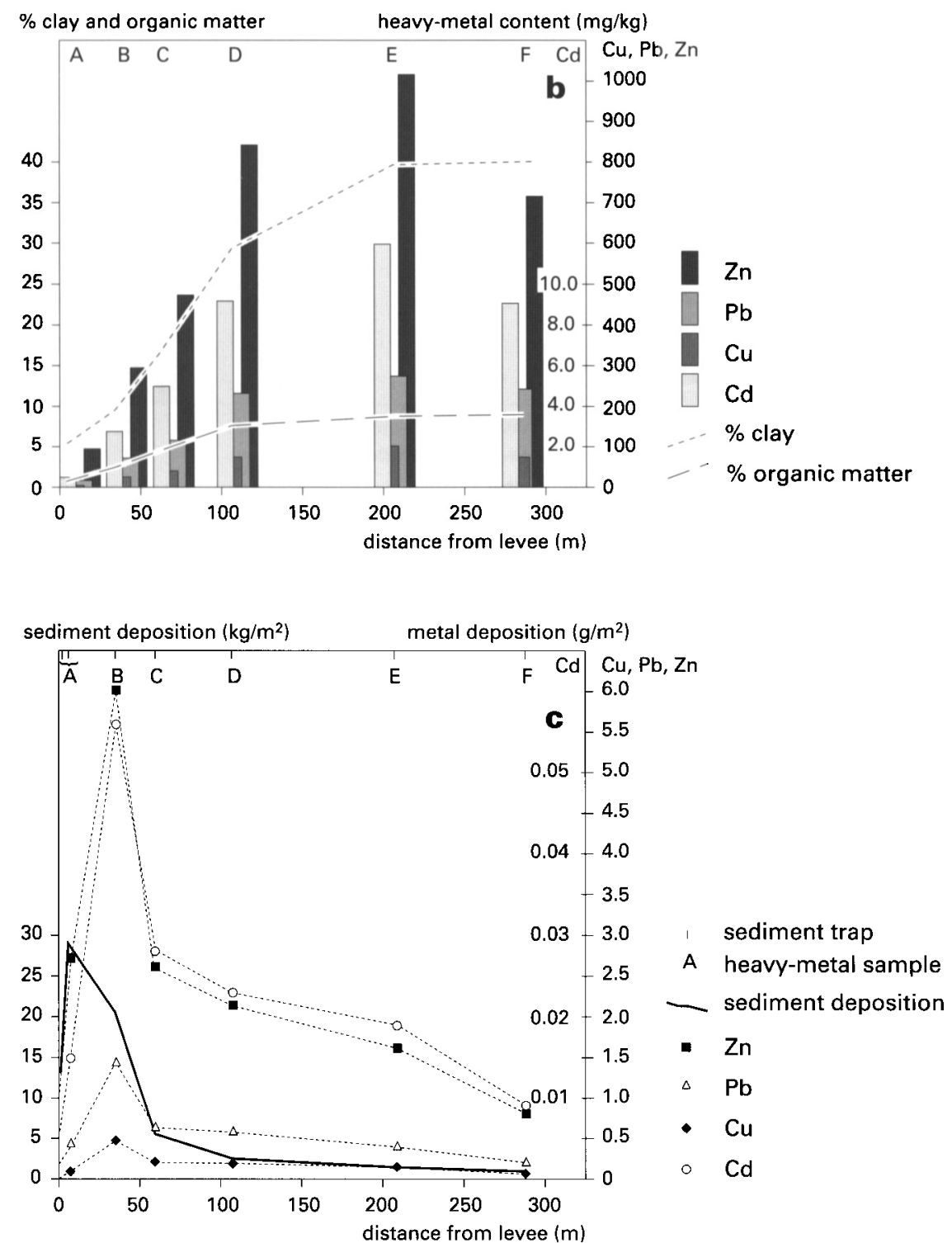

kg. It was estimated by multiplying these amounts by the average metal concentrations measured in each of the sediment types that the Waal deposited during the flood about $750 \mathrm{~kg} \mathrm{Cd}, 230 \mathrm{~kg} \mathrm{Cu}, 360 \mathrm{~kg} \mathrm{~Pb}$ and $143,000 \mathrm{~kg} \mathrm{Zn}$ on its floodplain (Table 4). This is about $17-25 \%$ of the total particulate-bound metal load transported during the flood by the Waal, and of the order of $5-10 \%$ of the total particulate-bound metal load transported in 1993 into the Netherlands by the Rhine. Metal accumulation of the embanked floodplains is thus an important factor when determining a heavy-metal balance for the Rhine-Meuse delta.

\section{Interpretation}

Sedimentation processes govern the spatial patterns of metal deposition during a flood. Variations in the percentages of clay and organic matter in the deposit- 
Table 3. Coefficients of regression between metal concentrations on the percentages of clay and organic matter. Old uncontaminated river sediments (deposited before 1750) and sediment deposited during the flood of December 1993 on the Waal en Meuse floodplains. Metal concentration $=b_{\mathrm{g}}+\mathrm{b}_{1} * \%$ clay $+\mathrm{b}_{2} \star \% \mathrm{OM}$.

\begin{tabular}{|c|c|c|c|c|}
\hline & $b_{0}$ & $b_{1}$ & $b_{2}$ & $\mathrm{R}^{2}$ \\
\hline \multicolumn{5}{|l|}{ zinc } \\
\hline uncontaminated & 46.1 & 1.00 & 1.00 & 0.66 \\
\hline Waal & 163.0 & 3.35 & 13.87 & 0.71 \\
\hline Meuse & 67.6 & 6.75 & 76.20 & 0.95 \\
\hline \multicolumn{5}{|l|}{ lead } \\
\hline uncontaminated & 22.0 & 0.50 & 0.25 & 0.48 \\
\hline Waal & 38.2 & 0.75 & 4.71 & 0.73 \\
\hline Meuse & 4.18 & 2.45 & 20.50 & 0.95 \\
\hline \multicolumn{5}{|l|}{ copper } \\
\hline uncontaminated & 5.5 & 0.46 & 0.99 & 0.66 \\
\hline Waal & 15.0 & 0.82 & 3.05 & 0.88 \\
\hline Meuse & 0.4 & 0.78 & 7.12 & 0.94 \\
\hline \multicolumn{5}{|l|}{ cadmium } \\
\hline uncontaminated & - & - & - & - \\
\hline Waal & 0.64 & 0.02 & 0.11 & 0.69 \\
\hline Meuse & -0.94 & 0.05 & 0.49 & 0.65 \\
\hline
\end{tabular}

ed sediment determine the differences in metal concentrations within a floodplain section. The amount of sediment deposition generally controls the deposition of metals. As a consequence, the spatial distribution of metal concentrations in sediments is often different from that of metal deposition. Spatial variations in sediment deposition are largely determined by the flow patterns during overbank flooding (Middelkoop \& Van der Perk, 1998). In those sections where a natural levee borders the main channel, sediment deposition decreases more or less exponentially with increasing distance from the main channel. Many floodplain sections, however, have a non-uniform topography with small embankments, former secondary channels, built-up areas and other obstacles to the water flow. Middelkoop \& Asselman (1998) and Middelkoop \& Van der Perk (1998) have demonstrated that this can result in complex patterns of the deposition of sediment and thus of heavy metals. Over a period of many years, metal accumulation will be highest in low-lying areas close to the main channel. Large amounts of sediments are deposited there already during low flow stages, when the metal
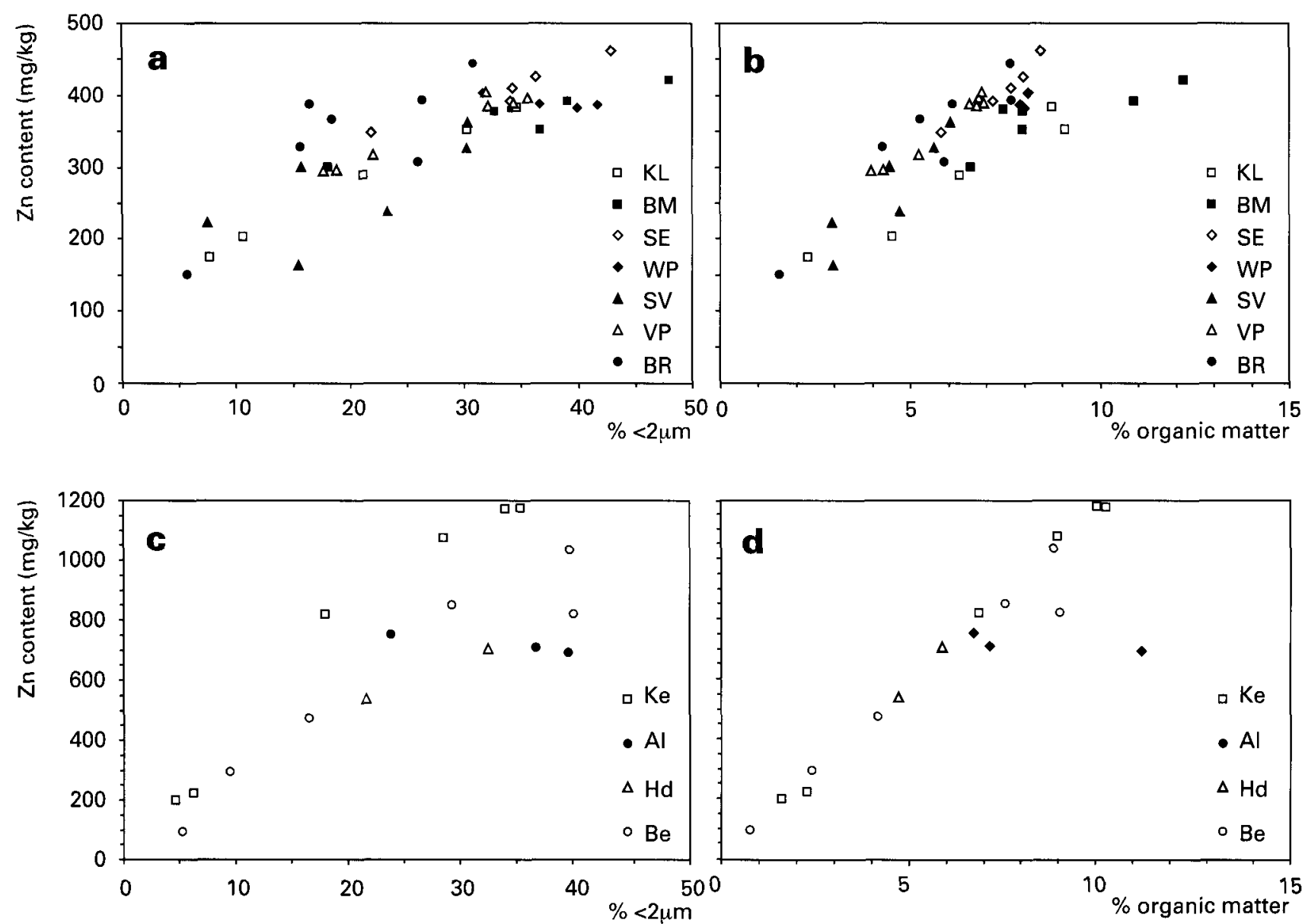

Fig. 6. Relationship between $\mathrm{Zn}$ concentration and percentages of clay and organic matter. a and $b$ : Waal floodplains.

$c$ and $\mathrm{d}$ : Meuse floodplains. 
Table 4. Metal deposition on the entire embanked floodplain of the Waal during the flood of December 1993.

\begin{tabular}{|c|c|c|c|c|c|c|}
\hline & & sediment & $\mathrm{Cd}$ & $\mathrm{Cu}$ & $\mathrm{Pb}$ & $\mathrm{Zn}$ \\
\hline \multicolumn{7}{|l|}{ metal deposition in sand sheets (bed load) } \\
\hline (a) sand deposition ${ }^{1}$ & $\left(10^{6} \mathrm{~kg}\right)$ & 350 & & & & \\
\hline (b) average metal concentration sediment & $(\mathrm{mg} / \mathrm{kg})$ & & 0.7 & 20 & 40 & 150 \\
\hline (c) metal deposition $(a \cdot b)$ & $\left(10^{3} \mathrm{~kg}\right)$ & & 0.25 & 7 & 14 & 53 \\
\hline \multicolumn{7}{|l|}{ metal deposition by suspended sediment } \\
\hline (d) clay and silt deposition & $\left(10^{6} \mathrm{~kg}\right)$ & 240 & & & & \\
\hline (e) average metal concentration sediment & $(\mathrm{mg} / \mathrm{kg})$ & & 2.1 & 65 & 90 & 375 \\
\hline (f) metal deposition $(\mathrm{d} \cdot \mathrm{e})$ & $\left(10^{3} \mathrm{~kg}\right)$ & & 0.50 & 16 & 22 & 90 \\
\hline total metal deposition $(c+f)$ & $\left(10^{3} \mathrm{~kg}\right)$ & & 0.75 & 23 & 36 & 143 \\
\hline \multicolumn{7}{|l|}{ metals transported by suspended sediment } \\
\hline \multicolumn{7}{|l|}{ * during the flood of 1993} \\
\hline (g) total suspended load Rhine at Lobith ${ }^{2}$ & $\left(10^{6} \mathrm{~kg}\right)$ & 1,950 & & & & \\
\hline (h) average conc. Rhine sediment at Lobith ${ }^{2}$ & $(\mathrm{mg} / \mathrm{kg})$ & & 1.6 & 65 & 88 & 395 \\
\hline (i) total metal load Rhine at Lobith ${ }^{2}(\mathrm{~g} \cdot \mathrm{h})$ & $\left(10^{3} \mathrm{~kg}\right)$ & & 3.1 & 127 & 172 & 770 \\
\hline (j) total metal load Waal ${ }^{3}(2 / 3 \cdot \mathrm{i})$ & $\left(10^{3} \mathrm{~kg}\right)$ & & 2.1 & 85 & 115 & 516 \\
\hline \multicolumn{7}{|l|}{ * over the entire year 1993} \\
\hline (k) total metal load Rhine at Lobith ${ }^{2}$ & $\left(10^{3} \mathrm{~kg}\right)$ & & 6.4 & 240 & 335 & 1560 \\
\hline (l) total metal load Waal $1993^{3}(2 / 3 \cdot \mathrm{k})$ & $\left(10^{3} \mathrm{~kg}\right)$ & & 4.3 & 160 & 223 & 1040 \\
\hline \multicolumn{7}{|l|}{ metals deposited by suspended sediment } \\
\hline \multicolumn{7}{|l|}{ proportion of total particulate-bound metal load } \\
\hline of the Waal during the flood $(f / j \bullet 100 \%)$ & $(\%)$ & & 24 & 19 & 19 & 17 \\
\hline \multicolumn{7}{|l|}{ proportion of total particulate-bound metal load } \\
\hline of the Rhine during the flood $(\mathrm{f} / \mathrm{i} \cdot 100 \%)$ & $(\%)$ & & 16 & 13 & 13 & 12 \\
\hline \multicolumn{7}{|l|}{ proportion of total particulate-bound metal load } \\
\hline of the Rhine at Lobith in $1993(\mathrm{f} / \mathrm{k} \cdot 100 \%)$ & $(\%)$ & & 8 & 7 & 7 & 6 \\
\hline
\end{tabular}

'Van Manen et al. (1994).

${ }^{2}$ Rijkswaterstaat (1994).

${ }^{3}$ the Waal discharges $2 / 3$ of the Rhine water.

concentrations in the river sediment are still higher than during periods of large discharge. In addition, large metal accumulations are expected in depressions and residual channels that often inundate and where fine humic sediments with high metal concentrations settle.

The results of the research into the deposition after the major flood of 1993 demonstrate the causes of the
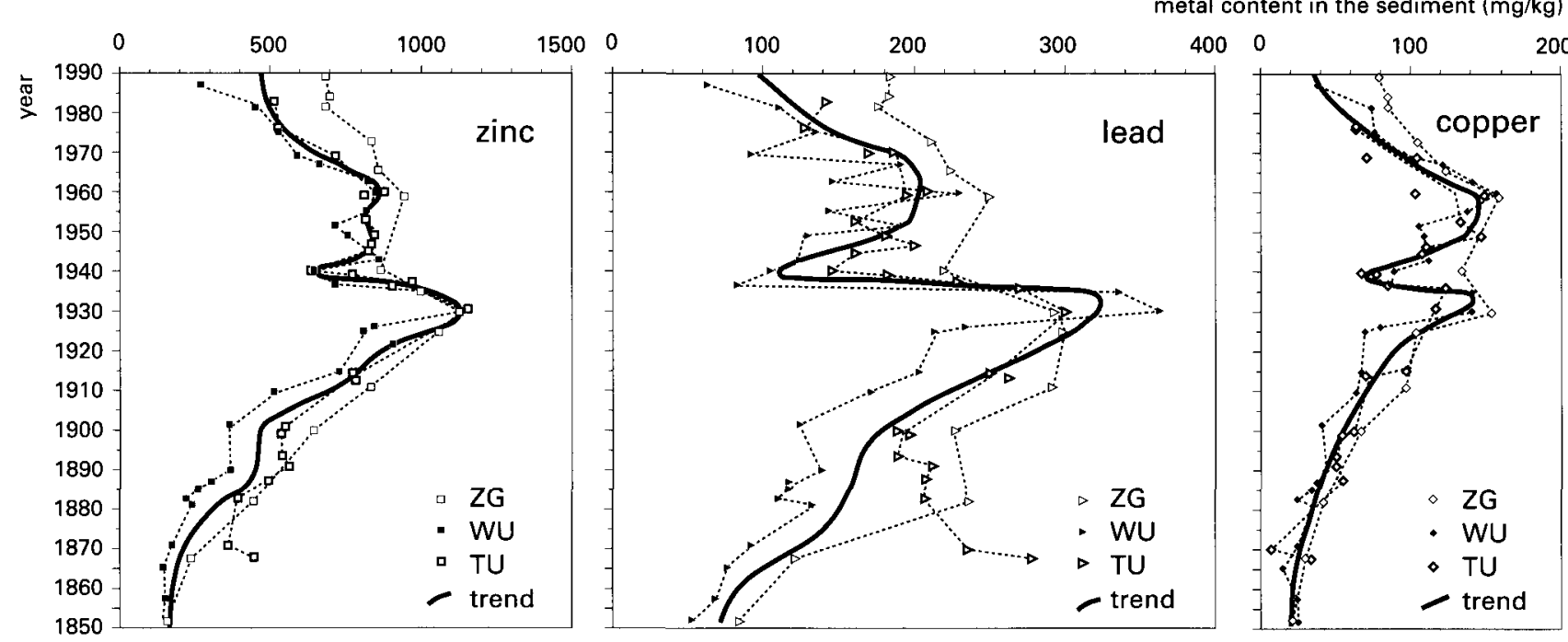

Fig. 7. Trends in the copper, lead and zinc contamination of sediment of the lower Rhine over the past 150 years. 
variation in metal pollution between the various locations within a floodplain, but they cannot explain the variation in metal concentrations in a vertical direction within the floodplain profiles. These are caused by the temporal changes in metal pollution of the Rhine that have occurred over the past century, as will be illustrated in the next section.

\section{Pollution history of the lower Rhine}

The metal concentrations in the cores from the three ponds (Zwarte Gat, Wamel and Tuil, Fig. 1b) have been plotted in Figure 7 . The chronological base of the metal records was obtained using the ${ }^{210} \mathrm{~Pb}$ datings and by comparing the results with the chronology of previous records established by Vink \& Winkels (1991), Winkels \& Van Diem (1991) and Beurskens et al. (1994). The upper sections of all profiles show strongly increased metal concentrations. The profile of Zwarte Gat shows less detail, because it is based on fewer samples than the Wamel and Tuil profiles. Metal concentrations in the Tuil profile are generally higher than in the Zwarte Gat and Wamel profiles.

The solid lines in Figure 7 show the trends that were obtained by averaging the measured metal concentrations at chronologically corresponding levels in
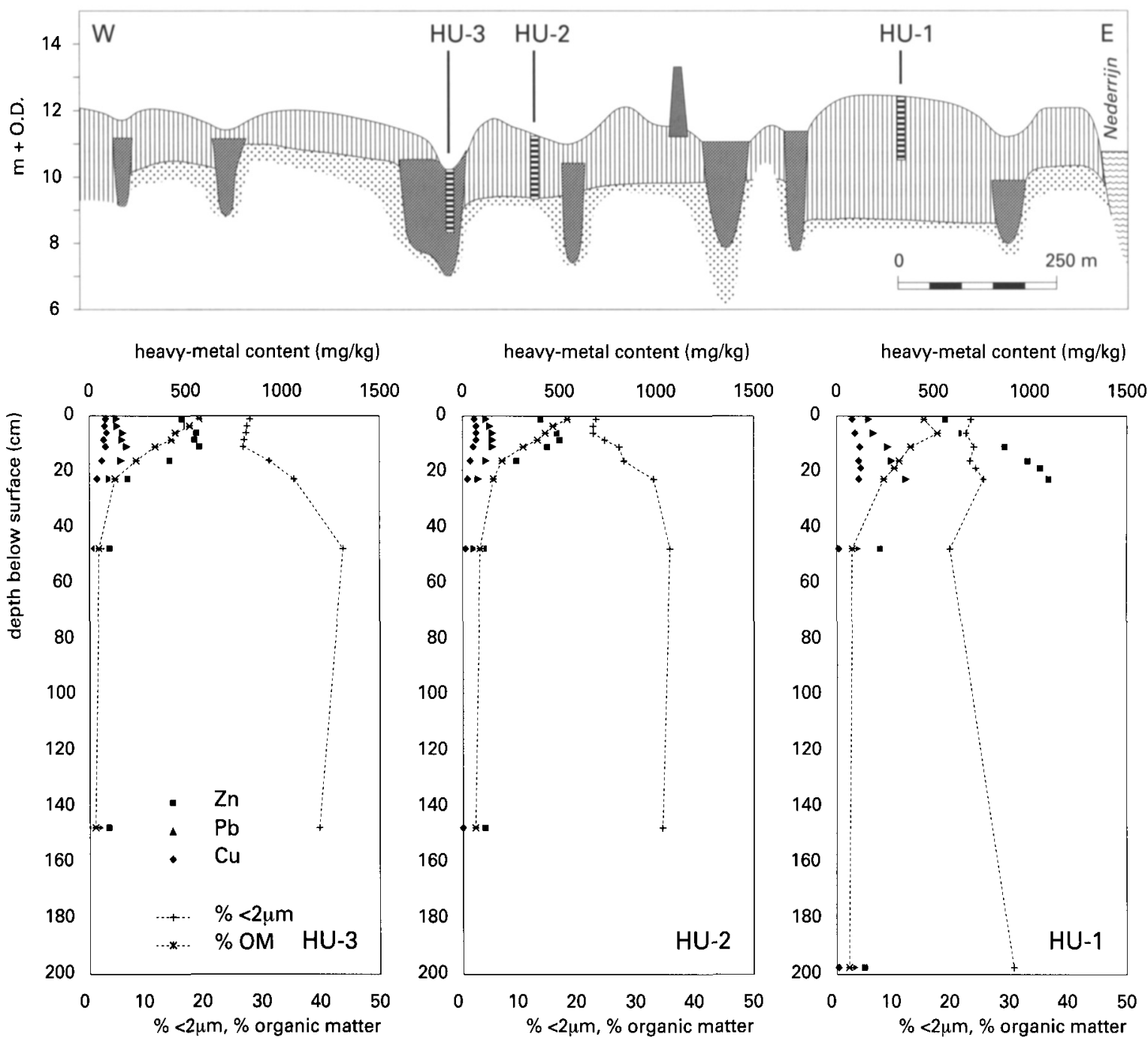

Legend to the cross-sections

embanked floodplains

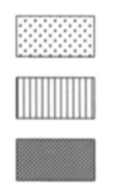

channel deposits

overbank deposits

residual channel deposits

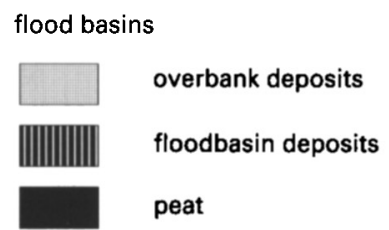

other

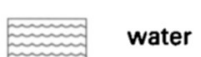

river dike

Fig. 8. Cross-section and heavy-metal profiles of the Huissen floodplain section. The metal concentrations have been standardised for differences in clay and organic-matter contents within the profiles. 
the three cores. The scatter around the trend lines may be attributed to year-to-year variations in metal concentrations, as well as changing metal concentrations during flood events. The solid curves do not reflect such annual fluctuations, but indicate the main trends of the upstream metal contamination of the Rhine and the resulting contamination of sediments, with an estimated temporal resolution of about five years.

The heavy-metal pollution history of the lower Rhine can be subdivided into several phases:

(1) before about 1860, the metal concentrations in the Rhine sediment were at low, pre-industrial values;

(2) from 1860 onwards, the river sediment became gradually contaminated with heavy metals;

(3) at the beginning of the twentieth century, a strong increase in metal contamination started, resulting in a maximum in the early 1930s. This period of high pollution is not comprised in previous reconstructions of the pollution history of the Rhine (a.o., Vink \& Winkels, 1991; Beurskens et al., 1994);
(4) during the period of World War II, the metal pollution temporarily decreased;

(5) after World War II, a second major increase of pollution started until the early 1960 s;

(6) between the early 1970s and about 1985, the heavy-metal pollution of the sediment was strongly reduced, as a result of the Rhine Action Plan;

(7) during the past decennium, the metal concentrations have decreased more slowly.

Those parts of the floodplain profiles that have been deposited in the twentieth century are expected to demonstrate more or less the same fluctuations in metal deposition as reconstructed from the ponds. Depending on the sedimentation rates and the subsequent degree of physical soil mixing processes and chemical re-distribution of the particulate-bound metals, the pollution may extend over shallow or large depths, and fluctuations in metal concentrations within the vertical profiles may have become more or less smoothed (Middelkoop, 1997). This was analysed by comparing metal profiles in flood-
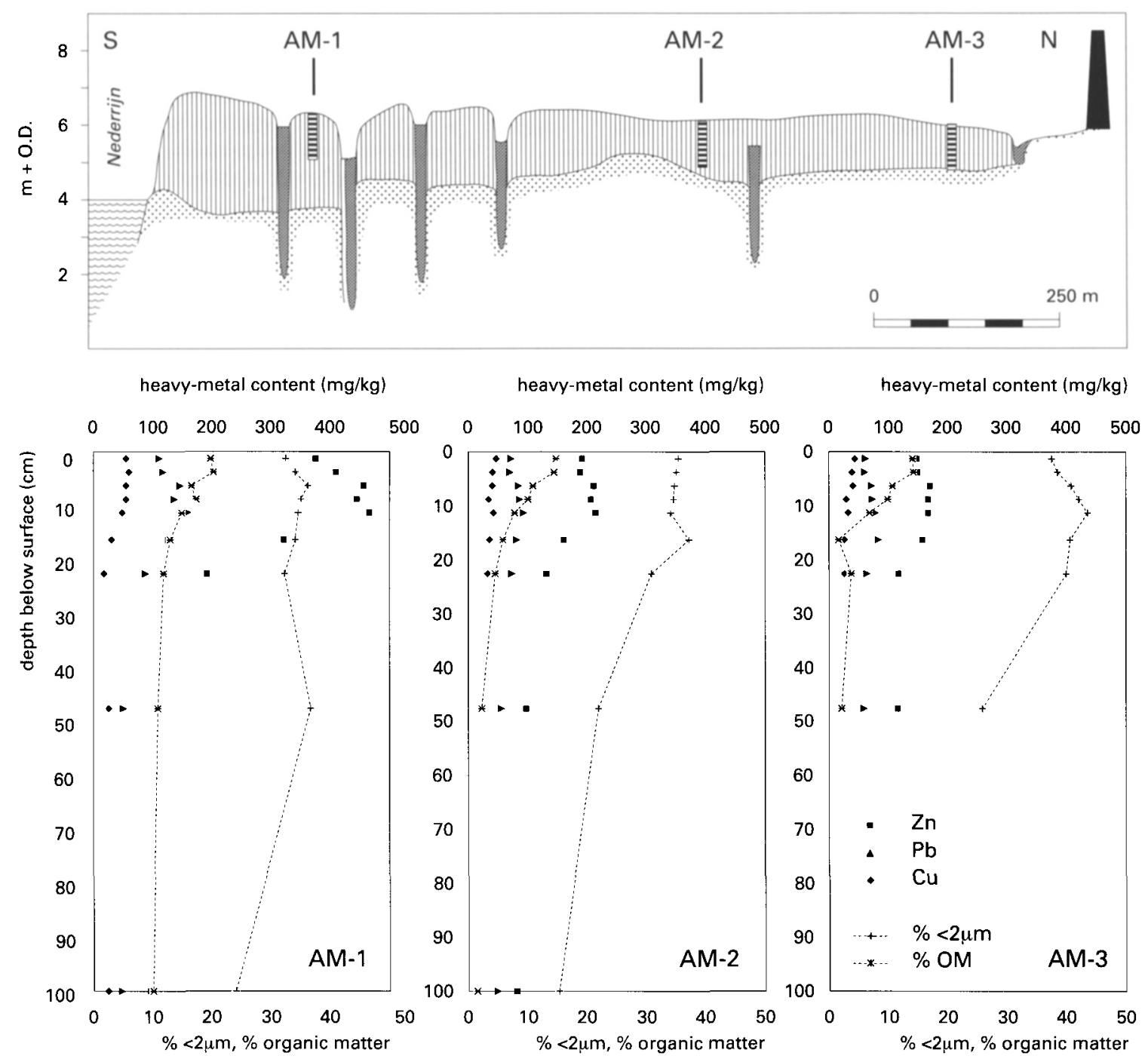

Fig. 9. Cross-section and heavy-metal profiles of the Amerongen (AM) floodplain section. 
plain soils from different parts of the lower Rhine floodplain.

\section{Heavy-metal profiles in floodplain soils}

Typical examples of heavy-metal profiles are shown in Figs. 8-11. Metal concentrations in the deepest parts of the profiles are at low, pre-industrial levels. They increase to a maximum with decreasing depth. Near the surface of many profiles, the decreased contamination of the Rhine sediment can be recognised. Maximum metal concentrations in the floodplain soils vary from 30 to $130 \mathrm{mg} / \mathrm{kg}$ for $\mathrm{Cu}$, from 70 to $490 \mathrm{mg} / \mathrm{kg}$ for $\mathrm{Pb}$, and from 170 to $1450 \mathrm{mg} / \mathrm{kg}$ for $\mathrm{Zn}$. To summarise the metal-profile characteristics, five indicators were defined:

- $\mathrm{D}_{1}$ : depth above which the metal concentrations strongly increase;

- $\mathrm{D}_{\mathrm{K}}$ : depth of the maximum metal concentration;

- $\mathrm{C}_{\mathrm{x}}$ : maximum metal concentration within the profile;
- $\mathrm{C}_{18}$ : average metal concentration in the upper 10 $\mathrm{cm}$ of the profile. This indicator was used in sanitation surveying studies of the embanked floodplains to determine the extent of the floodplain soil pollution;

- $M$ : total amount of heavy metals present per $\mathrm{m}^{2}$ in the entire profile being the excess over the background value. $M$ is calculated by multiplying the depth-averaged excess concentration by the bulk density $\left(1200-1400 \mathrm{~kg} / \mathrm{m}^{3}\right)$.

The values or estimated ranges of the characteristics of the $\mathrm{Zn}$ profiles from the investigated floodplain sites are listed in Table 5. The ranges found for the characteristics are very large. For the example of $\mathrm{Zn}$ : $\mathrm{D}_{\mathrm{i}},=0.175-2 \mathrm{~m} ; \mathrm{D}_{\mathrm{s}},=0.05-1.0 \mathrm{~m} ; \mathrm{C}_{\mathrm{x}}=170-1450$ $\mathrm{mg} / \mathrm{kg} ; \mathrm{C}_{10}=156-890 \mathrm{mg} / \mathrm{kg} ; \mathrm{M}=22-1400 \mathrm{~g} / \mathrm{m}^{2}$.

The main differences between the profiles may be summarised as follows:

- Both the total and maximum metal contents in the Waal floodplain are generally higher than those in the Nederrijn-Lek and IJssel floodplains. The
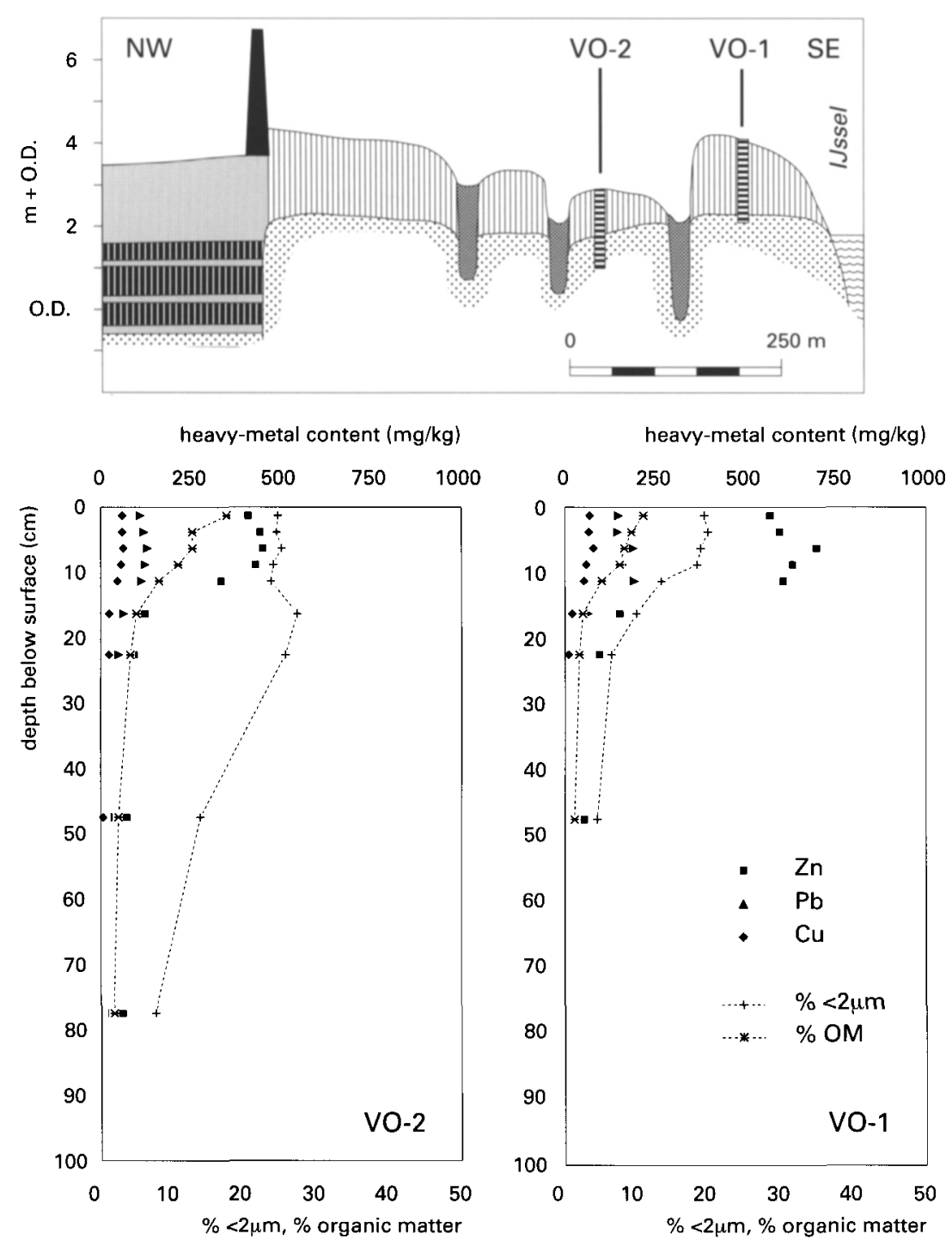

Fig. 10. Cross-section and heavy-metal profiles of the Vorchten (VO) floodplain section. 
smallest amounts of metals are found behind a minor dike and in the distal parts of the floodplain of the Nederrijn-Lek (see, for instance, the Amerongen profile: AM3, Fig. 9).

- Low floodplain sections along the Waal that are not bordered by a minor river dike are contaminated by heavy metals to a great depth, usually more than $1 \mathrm{~m}$ below surface. As a result of the decreasing sediment contamination over the past thirty years, the metal concentrations in the upper parts of these profiles are lower than the concentrations at several dm depth. The Klompenwaard (Fig. 11) and Varikse Plaat profiles demonstrate this.

- The metal pollution is much greater in the natural levees and at a short distance from the main channel than in the distal parts or behind a minor dike. These differences are demonstrated in the profiles of Huissen (Fig. 8), Amerongen (Fig. 9) and Vorchten (Fig. 10). In most cases, the metal con- tent of the profiles decreases with increasing distance to the main channel (e.g. Amerongen, Fig. 9), but these differences do not show up in the Bronkhorst and Slijk-Ewijk areas. Metal accumulations in depressions are slightly greater than at nearby elevated sites. The absence of the pollution trends within the KL3 profile (Fig. 11) suggests that the depression from which it was taken has been partly filled-in by human activities.

The temporal changes in the metal contamination of the Rhine sediment are reflected in all investigated profiles. The profiles where the increased metal concentrations extend to a great depth and with highest maximum concentrations (e.g., in Klompenwaard) have developed at sites where sedimentation rates have been high. These profiles also display well the recent improvement of the chemical quality of the Rhine. The metal concentrations in the upper $10 \mathrm{~cm}$ may be $2-3$ times as low as the maximum concentra-
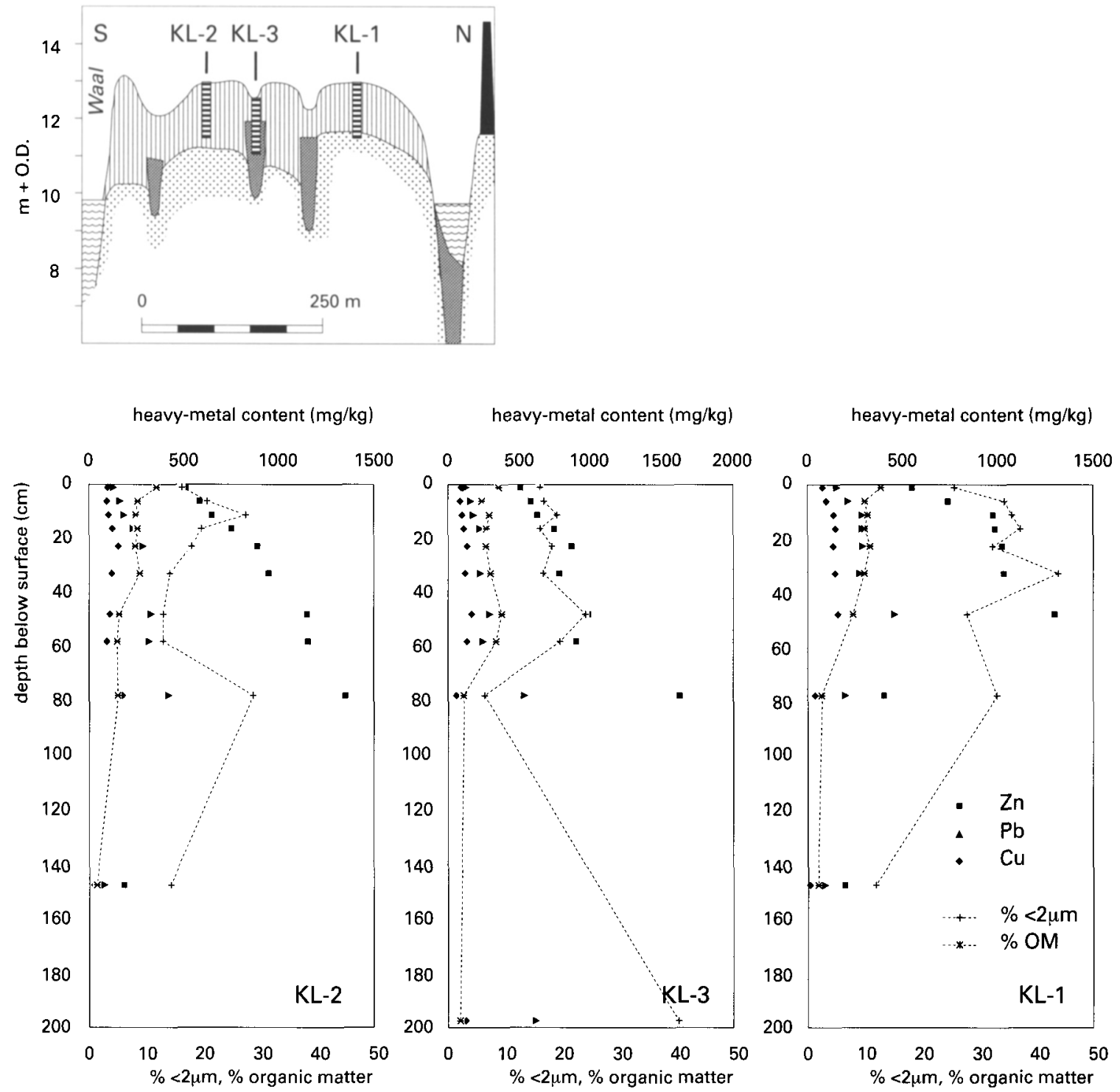

Fig. 11. Cross-section and heavy-metal profiles of the Klompenwaard $(\mathrm{KL})$ floodplain section. 
Table 5. Zn-profile characteristics of the investigated floodplain profiles.

\begin{tabular}{|c|c|c|c|c|c|}
\hline & $\mathrm{D}_{\mathbf{i}}(\mathrm{cm})$ & $\mathrm{D}_{\mathbf{x}}(\mathrm{cm})$ & $\mathrm{C}_{\mathrm{x}}(\mathrm{mg} / \mathrm{kg})$ & $\mathrm{C}_{10}(\mathrm{mg} / \mathrm{kg})$ & $M\left(\mathrm{~g} / \mathrm{m}^{2}\right)$ \\
\hline \multicolumn{6}{|c|}{ Nederrïn - Lek } \\
\hline $1 \quad \mathrm{AM} 1$ & $25-35$ & $10-12.5$ & 466 & 421 & 100 \\
\hline $2 \quad \mathrm{AM} 2$ & $25-30$ & $10-12.5$ & 214 & 199 & 32 \\
\hline 3 AM3 & $17.5-20$ & $5-12.5$ & 170 & 158 & 23 \\
\hline $4 \quad \mathrm{~KB} 2$ & $30-35$ & $15-20$ & 200 & 187 & 29 \\
\hline $5 \mathrm{~KB} 3$ & $27-32$ & $20-25$ & 169 & 156 & 22 \\
\hline 6 HU1 & $35-45$ & $20-30$ & 1094 & 600 & 529 \\
\hline 7 HU2 & $17.5-20$ & $7.5-10$ & 499 & 465 & 106 \\
\hline 8 HU3 & $25-30$ & $10-12.5$ & 568 & 520 & 119 \\
\hline \multicolumn{6}{|l|}{ IIfsel } \\
\hline $9 \mathrm{BH} 1$ & $25-35$ & $10-12.5$ & 647 & 530 & 109 \\
\hline $10 \mathrm{BH} 2$ & $17.5-20$ & $5-10$ & 499 & 478 & 61 \\
\hline $11 \mathrm{VO} 1$ & $17.5-20$ & $5-7.5$ & 698 & 622 & 90 \\
\hline $12 \mathrm{VO} 2$ & $17.5-20$ & $5-7.5$ & 450 & 433 & 53 \\
\hline \multicolumn{6}{|l|}{ Waal } \\
\hline $13 \mathrm{KL} 1$ & $100-150$ & $40-50$ & 1295 & 642 & 953 \\
\hline $14 \mathrm{KL} 2$ & $100-150$ & $70-100$ & 1352 & 548 & 1398 \\
\hline 15 WI4 & $50-60$ & $10-15$ & 819 & 651 & 281 \\
\hline 16 WI5 & $80-150$ & $30-50$ & 1394 & 683 & $?$ \\
\hline 17 SE1 & $25-50$ & $7.5-10$ & 1132 & 890 & 325 \\
\hline 18 SE2 & $50-80$ & $15-40$ & 1129 & 790 & $?$ \\
\hline 19 WP1 & $45-60$ & $15-25$ & 512 & 461 & 203 \\
\hline $20 \mathrm{WP} 2$ & $50-70$ & $20-30$ & 640 & 490 & 258 \\
\hline $21 \mathrm{WP} 3$ & $50-70$ & $5-15$ & 800 & 635 & 334 \\
\hline $22 \mathrm{WP} 4$ & $30-45$ & $20-25$ & 521 & 472 & 172 \\
\hline $23 \mathrm{VP1}$ & $150-200$ & $40-60$ & 1309 & 518 & 1081 \\
\hline 24 BR1 & $150-200$ & $45-50$ & 1453 & 654 & 1373 \\
\hline $25 \mathrm{BR} 2$ & $50-60$ & $10-15$ & 514 & 455 & 175 \\
\hline $26 \mathrm{BR} 3$ & $60-80$ & $15-20$ & 1166 & 832 & 455 \\
\hline 27 BR4 & $50-60$ & $10-15$ & 540 & 420 & 208 \\
\hline 28 BR5 & $40-60$ & $5-10$ & 491 & 469 & 184 \\
\hline
\end{tabular}

$D_{\mathbf{i}}=$ depth of lower boundary of increased $\mathrm{Zn}$ concentrations; interval indicates uncertainty range.

$\mathrm{D}_{\mathbf{x}}=$ depth at which maximum $\mathrm{Zn}$ concentration occurs; interval indicates uncertainty range.

$\mathrm{C}_{\mathrm{K}}=$ maximum $\mathrm{Zn}$ concentration within the profile.

$\mathrm{C}_{10}=\mathrm{Zn}$ concentration in the upper $10 \mathrm{~cm}$ of the profile.

$M=$ total excess amount of $\mathrm{Zn}$ in the profile.

tions. The profiles that are only contaminated in the upper $10-20 \mathrm{~cm}$ reflect low sedimentation rates (e.g., in the Amerongen profile AM3) where the maximum metal concentrations are lower. This may be due to the relatively wide sample depths compared to the metal fluctuations in the profiles. In addition, the smoothing effect of soil mixing on the metal concentrations is relatively strong when sedimentation rates are low.

\section{Estimation of sedimentation rates}

By assigning the ages of characteristic changes in the metal pollution to the corresponding depths in the metal profiles, an estimate of the average sedimentation rates over the past century was obtained. This was done on the basis of (1) the depth above which the concentrations strongly increase $\left(D_{i}\right)$, and (2) the depth of the maximum concentration in the profile $\left(D_{\mathrm{H}}\right)$.

As a result of soil mixing and the sample widths, the two maxima in the pollution history could not be distinguished in profiles with a low sedimentation rate. The depth of maximum concentrations in these profiles may, therefore, correspond to the 1935-1960 period. The results given in Table 6 indicate that the sedimentation rates range from less than $1 \mathrm{~mm} / \mathrm{a}$ for the floodplains of the IJssel and Nederrijn-Lek rivers to about $15 \mathrm{~mm} / \mathrm{a}$ for low lying parts of the Waal floodplain.

\section{Implications for pollution surveys}

Complex patterns of water flow and deposition that 
Table 6. Estimated ranges of sedimentation rates for different groups of floodplain sites, based on the depths of onset of pollution and maximum pollution.

\begin{tabular}{|c|c|}
\hline location & $\begin{array}{l}\text { average } \\
\text { sedimentation } \\
\text { rate }(\mathrm{mm} / \mathrm{a})\end{array}$ \\
\hline Rhine/IJssel floodplain, natural levee & $<1-2.5$ \\
\hline Rhine/IJssel, central part of floodplain & $2.5-6$ \\
\hline Rhine/IJssel floodplain, depression & $2.5-6$ \\
\hline Waal, central part of floodplain & $4-6$ \\
\hline Waal, low floodplain & $15-18$ \\
\hline
\end{tabular}

occur during floods (Middelkoop \& Asselman, 1998; Middelkoop \& Van der Perk, 1998) may cause that correlations between metal pollution of a soil versus factors such as distance to the main channel, local elevation or flooding frequency are low when larger areas are considered. Because of the reduction in pollution over the past decades, inventories of the metal pollution of the floodplains of the Rhine should not be based on shallow samples (see Hoogerwerf, 1992). This can be well illustrated when the total (excess) $\mathrm{Zn}$ content, $\mathrm{M}$, in each soil profile is plotted against the average $\mathrm{Zn}$ concentration in the upper 10 $\mathrm{cm}$ of the profile, $\mathrm{C}_{10}$ (Fig. 12). Particularly in those areas where the sedimentation rate is more than about 3-5 $\mathrm{mm}$ per year, the reduction of the river pollution over the past 25 years has resulted in relatively low metal concentrations in the upper parts of the soil profiles.

In a few profiles (KL1, WI5, SE1, SE2 and BR3), metal concentrations in the upper $10 \mathrm{~cm}$ seem to be high when compared with the total metal contents in the profiles. At these sites, the sedimentation rate has probably decreased during the period of improving sediment quality.

\section{Conclusions}

Spatial variations in metal concentrations in overbank sediment deposited during a flood are controlled by differences in the clay and organic matter contents in the sediment. The patterns of metal deposition, however, are generally determined by the amounts of sediment deposited. Sedimentation patterns, in turn, are controlled by the flow patterns during overbank flooding. In floodplains where a natural levee borders the main channel, sediment deposition - and hence metal deposition - decreases more or less exponentially with the distance from the main channel. In the many floodplain sections with a non-uniform topography, however, the pattern of metal deposition may be more complex. On the long term, the largest amounts of metals will accumulate nearby the natural levee, and in low-lying areas that are frequently inundated and where large amounts of fine sediments are deposited.

The metal contamination of the sediment that the Rhine has deposited on its floodplain has varied greatly over the past hundred years. Maximum pollution occurred in the 1930s and 1960s, when $\mathrm{Cu}, \mathrm{Pb}$ and $\mathrm{Zn}$ concentrations were about 6-10 times as high as background values. A considerable reduction in the contamination has been achieved in the 1975-1985 period.

The resulting spatial variation in the concentrations of $\mathrm{Cd}, \mathrm{Cu}, \mathrm{Pb}$ and $\mathrm{Zn}$ in the soils of the embanked floodplains along the lower Rhine distributaries is

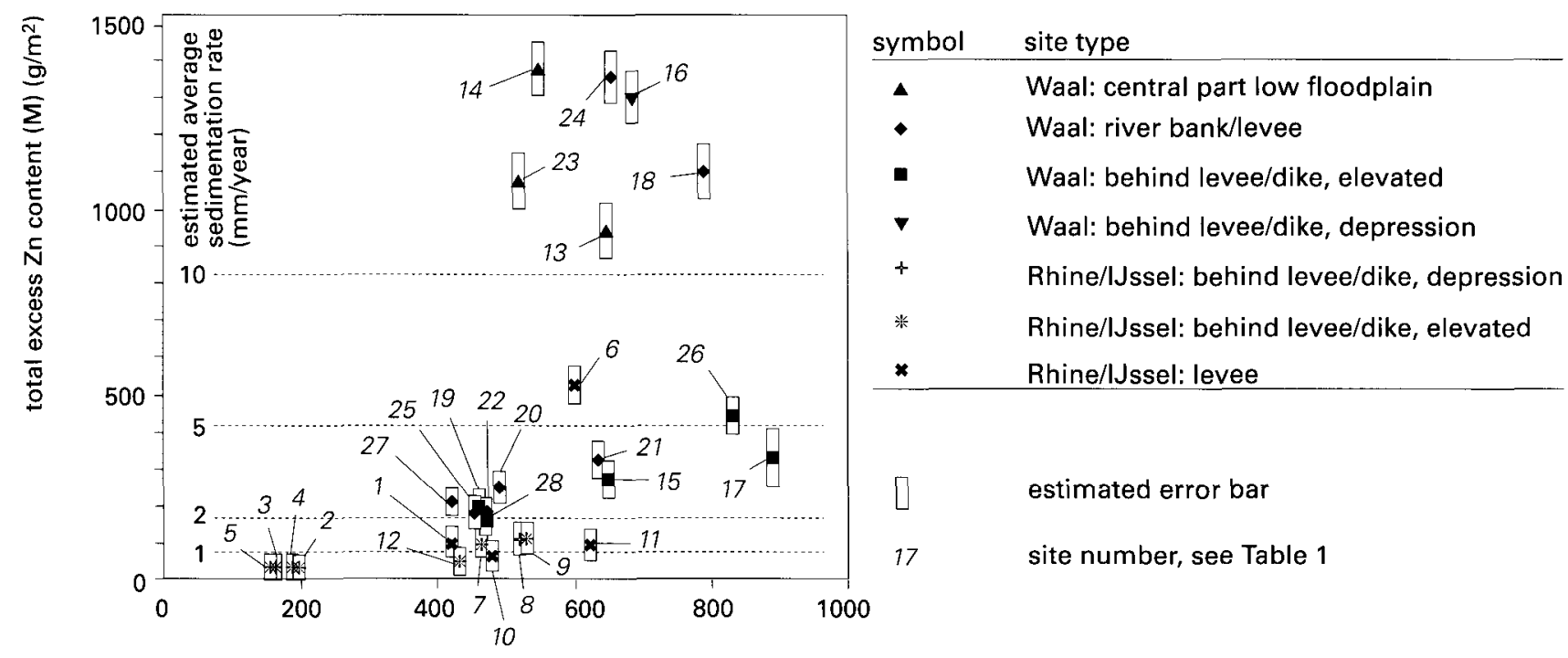

$\mathrm{Zn}$ concentration in the upper $10 \mathrm{~cm}\left(\mathrm{C}_{10}\right)(\mathrm{mg} / \mathrm{kg})$

Fig. 12. Relationship between total zinc excess in the entire floodplain soil profile $(M)$ and average zinc concentrations in the upper $10 \mathrm{~cm}$ $\left(\mathrm{C}_{10}\right)$ for several sites along the Rhine distributaries. 
large, both along the river and across overbank deposits. Maximum metal concentrations in the lower Rhine floodplain soils vary from 30 to $130 \mathrm{mg} / \mathrm{kg}$ for $\mathrm{Cu}$, from 70 to $490 \mathrm{mg} / \mathrm{kg}$ for $\mathrm{Pb}$, and from 170 to $1400 \mathrm{mg} / \mathrm{kg}$ for $\mathrm{Zn}$. The lowest metal pollution is found in floodplain sections with low flooding frequencies along the Nederrijn-Lek and IJssel, at several hundreds of metres distance from the main channel. There, average sedimentation rates over the past century have been less than about $2 \mathrm{~mm} / \mathrm{a}$. The largest metal accumulations occur along the Waal in low-lying floodplain sections without a minor dike, where sedimentation rates have been in the order of $10 \mathrm{~mm} / \mathrm{a}$.

Due to the complex patterns of metal deposition that may occur in floodplains with a non-uniform topography, correlations between metal pollution in a soil against variables such as distance to the main channel, local elevation or flooding frequency will be low when large floodplain areas are considered. Because of the variation in pollution over the past century, inventories of the metal pollution of the lower Rhine floodplains should not be based on shallow samples. Pollution surveys should therefore account for the water-flow patterns that may occur over the floodplain when designing a sampling scheme. The depth over which the pollution extends within the soil profiles must be determined at several representative sites within the floodplain, and the overall inventory should be based on the total excess metal content in the entire soil profile.

\section{Acknowledgements}

The author wishes to thank the Dutch Institute for Inland Water Management and Waste Water Treatment for providing data on river discharge, suspended sediment concentrations and heavy metals for the Rhine and Meuse. Two reviewers are acknowledged for their useful comments on this paper.

\section{References}

Beurskens, J.E.M., Winkels, H.J., De Wolf, J. \& Dekker, C.G.C., 1994. Trends of priority pollutants in the Rhine during the last fifty years. Water Science \& Technology 29:77-85.

Burrough, P.A., Van Rijn, R. \& Rikken, M., 1993. Spatial data quality and error analysis issues: GIS functions and environmental modelling. Proceedings of the Second International Conference on Integrating Geographic Information Systems and Environmental Modelling (Breckenridge, Colorado September 1993): $14 \mathrm{pp}$.
Dominik, J., Mangini, A. \& Müller, G., 1981. Determination of recent deposition rates in Lake Constance with radioisotopic methods. Sedimentology 28: 653-677.

Heijnis, H., Berger, G.W. \& Eisma, D., 1987. Accumulation rates of estuarine sediment in the Dollard area; comparison of $210 \mathrm{~Pb}$ and pollen influx methods. Netherlands Journal of Sea Research 21:295-301.

Hoogerwerf, M.R., 1992. Onderzoek naar de relatie tussen verontreiniging van de uiterwaarden en relatieve terreinhoogten. Internal Report CSO (Den Dolder) CSO.92.030: $61 \mathrm{pp}$.

Kos, Th.J.M., 1994. Meetverslag zwevend stof metingen in de Maas tijdens hoogwater December 1993. Internal Document RIZA (Arnhem) 94.160X: 25 pp.

Leenaers, H., 1989. The dispersal of metal mining wastes in the catchment of the river Geul (Belgium - the Netherlands). Netherlands Geographical Studies 102: 1-230.

Middelkoop, H., 1997. Embanked floodplains in the Netherlands. Geomorphological evolution over various time scales. Netherlands Geographical Studies 224: 1-352.

Middelkoop, H. \& Asselman, N.E.M., 1998. Spatial variability of floodplain sedimentation at the event scale in the Rhine-Meuse delta, the Netherlands. Earth Surface Processes and Landforms 23: 545-559.

Middelkoop, H. \& Van der Perk, M., 1998. Modelling spatial patterns of overbank sedimentation on embanked floodplains. Geografiska Annaler 80A: 95-109.

NNI (Nederlands Normalisatie Instituut), 1981. NEN 6465 - Water and air sample preparation for sludge, water-containing sludge and air dust for the determination of elements by atomic adsorption spectrometry - Destruction with nitric acid and hydrochloric acid. NNI (Delft): $4 \mathrm{pp}$.

NNI (Nederlands Normalisatie Instituut), 1992a. NEN 5753 Bepaling van de korrelgrootteverdeling met behulp van zeef en pipet (ontwerpnorm). NNI (Delft): $22 \mathrm{pp}$.

NNI (Nederlands Normalisatie Instituut), 1992b. NEN 5754 Bodem-bepaling van het gehalte aan organische stof in grond volgens de gloeiverliesmethode. NNI (Delft): 4 pp.

Rang, M.C., Klein, C.E. \& Schouten, C.J., 1987. Mapping of soil pollution by application of classical geomorphological and pedological field techniques. In: Gardiner, V. (ed.): International Geomorphology Part 1. Wiley \& Sons (New York): 1029-1044

Rijkswaterstaat, 1994. Jaarboek monitoring rijkswateren 1993. Rijkswaterstaat (Den Haag): 163 pp.

Rikken, M.G.J. \& Van Rijn, R.P.G., 1993. Soil pollution with heavy metals. An inquiry into the spatial variation, cost of mapping and risk-evaluation of copper, cadmium, lead and zinc in the floodplains of the Meuse West of Stein, the Netherlands. Internal M.Sc. thesis, Department of Physical Geography, Utrecht University: $73 \mathrm{pp}$.

Van Manen, G.R., Onneweer,Y. \& Berendsen, H.J.A., 1994. Inventarisatie van de sedimentatie van zand op de oeverwallen van de Waal tijdens het hoogwater van December 1993 - januari 1994. Internal Report GEOPRO (Department of Physical Geography, Utrecht University) 1994.06: $11 \mathrm{pp}$.

Vink, J.P.M. \& Winkels, H.J., 1991. Opbouw en kwaliteit van de waterbodem van het IJsselmeer. Flevobericht 326 (Rijkswaterstaat, Directie Flevoland, Lelystad): 112 pp.

Winkels, H.J. \& Van Diem, A., 1991. Opbouw en kwaliteit van de waterbodem van het Ketelmeer. Flevobericht 325 (Rijkswaterstaat, Directie Flevoland, Lelystad): $98 \mathrm{pp}$. 


\section{Advertising in Netherlands Journal of Geosciences?}

Contact: Mrs. Tonny Handgraaf at Retra Publiciteitsservice b.v. Telephone: +31-(0)23-5718480

Fax: $\quad+31-(0) 23-5716002$

E-mail: $\quad$ retra@retra-ps.demon.nl 